\title{
Enhancing Rural Manufacturers' Competitiveness Through Design Automation For New Product Development
}

\author{
Gary McCain, (E-mail: gmccain@boisestate.edu), Boise State University \\ Stephen A. Tennyson, (E-mail: stennyson@boisestate.edu), Boise State University \\ Rudolph J. Eggert, (E-mail: reggert@boisestate.edu), Boise State University \\ Steven A. Hatten, (E-mail: shatten@boisestate.edu), Boise State University
}

\begin{abstract}
The competitiveness of third world manufacturing has placed pressure on U.S. manufacturers to create new products to survive. Computer aided solid modeling and rapid prototyping technologies accelerate new product development, but rural manufacturers are often left behind. This paper describes a cooperative venture between a state university and a federal agency to improve the new product development process of selected rural manufacturers by introducing them to leading-edge design automation technologies. Use of these tools allows better crossfunctional communication among top management, marketing, designers, engineers, and manufacturing as they proceed through the new product creation process. Participating companies produced new product options, enhanced employment, and increased revenues.
\end{abstract}

\section{Introduction}

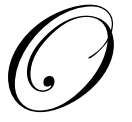

ne of the major economic issues in the industrial world has been the transferal of jobs from the more developed nations to the less developed nations. One can hardly pick up a newspaper or business magazine without reading of another example of a manufacturer downsizing domestic production to outsource them to some other country. Estimates of as many as three million lost jobs in the United States have made outsourcing a hot topic for the 2004 presidential race. European nations have seen thousand of jobs leave their borders (Matlack 2004). Numerous protectionist remedies to constrain the export of jobs have been proposed, both in the U.S. (Annett 2004) and Europe (Roth et. al. 2004). Now that service and technology outsourcing have become prevalent, what manufacturers have known for ages is becoming recognized as a common factor to all business. If someone somewhere else can do the job as well but cheaper, the job will go to him.

One can try to fight the phenomenon or try to understand it and prepare for the future. David Wessel (2004) wrote that we are not "going to run out of jobs, even though history shows that it's impossible to predict what new jobs will replace those that are destroyed. The bad news: Outsourcing overseas and technology could widen the gap between the wages of well-paying brainpower jobs and poorly paid hands-on jobs." From the example of early British weaving (Davis 2004) to the more recent outsourcing of Volkswagen's Santana model to Shanghi (Webb 2003), history tells us that even high-skilled jobs can be outsourced when the technologies of production get exported. Jobs that can be reduced to a series of rules are likely to go -- either to workers abroad or to computers. "The jobs that stay ... or that are newly created in the decade ahead are likely to demand the more complex skill of recognizing patterns or require human contact. (Wessel 2004)" An example of insourcing jobs requiring more complex skills is the decision of Novartis to move 600 designer drug research jobs from the traditional pharmaceutical centers of Europe to a Cambridge, Massachusetts to take advantage of the intense bioresearch community in the area (Aoki 2003).

When low paying, easily taught or automated jobs leave, it becomes necessary for nations, states, and communities that want to stay economically viable to find ways to provide environments where their companies and 
workers can become capable of applying more advanced technological skills that sustain continued economic growth and well being. To avoid losing jobs to low wage countries, companies must be at the leading edge of technology and product development. Communities with older generation technologies, production tools, and designing approaches will have to catch up or find themselves watching their jobs leave.

\section{Technical Designing in the State of Idaho}

The economy in the state of Idaho has rapidly expanded over the last decade to include more and more communities that rely on design and manufacturing industries to help support their livelihood. Data available through the Idaho Department of Commerce and the U.S. Department of Commerce substantiate this. For instance, in 1997, the State of Idaho generated net exports of 1.5 billion US dollars. Of that amount, 1.25 billion US dollars was in manufactured products, equipment and technology products (State of Idaho 1998). Yet, a 1998-99 study of Idaho's design and manufacturing industries uncovered deficiencies that were jeopardizing the competitiveness of many surveyed. Compared to usually larger and more progressive companies in other states, many were using outdated software for new product design rather than solid-modeling design software, and computer-aided analysis software. Few were aware of the existence rapid prototyping technologies, let alone apply them (Tennyson and Eggert 2000).

Traditionally, the design process had involved creating static views of individual product components on separate drawings according to a standardized format. Then the components were put together in an assembly on another static drawing. Engineers invariably make numerous errors due to cognitive misunderstandings and misinterpretations of the very images that they are creating. The various decision makers from design, to marketing, to manufacturing may have different understandings of how to interpret these drawings. This in turn increases the cost and duration of product development time due to numerous design iterations. The latest design software, solid modeling, allows designers to create three-dimensional images of parts, and the entire product composed of these parts, that can be manipulated within the virtual space of the computer. The ability to manipulate realistic images of virtual objects greatly benefits visualization during the design process.

A technology developed during the 1990s, rapid prototyping, allows engineers to create physical prototypes of product concepts from solid models right in the design office, typically in a matter of a few hours. A service industry has evolved to provide these services to companies too small to support the capital investments in this kind of equipment. Solid model computer files may be sent by e-mail and physical prototypes, created in plastic, may be express shipped back within a few days. Application of these technologies can dramatically reduce the timeto-market of new product concepts. Rural locations do not have to be excluded from participation at the highest levels of competitiveness.

A later study by McCain and Tennyson (2001) of companies that both designed and prototyped their own products revealed increases in solid modeling but a continuing low level of rapid prototyping. Those companies that had advanced to solid modeling cited its ease of use and perceived efficiencies as benefits. Half of the companies interviewed still did not use solid modeling, and two-thirds of those did not intend to switch within the next two years. They cited cost of conversion and doubts about its benefits as obstacles to adoption. Thirty had never used any type of rapid prototyping; of these, only twelve said they expected to try it within two years. The major reasons for not adopting it were that traditional prototyping is adequate and an admitted lack of knowledge about any benefits of rapid prototyping.

The above studies demonstrated that smaller companies, particularly those located in economically distressed rural areas of Idaho, tend to lag behind in use of design automation. In particular, these companies need to discover the value-added benefit of solid modeling and rapid prototyping. Application of such technologies has proven particularly effective early in product development. Early changes in the development of a product are the easiest and least expensive to make and furthermore, they have the greatest impact on the cost and time to develop the final product (Smith 2001). Companies adapting such design automations would likely improve their capability to bring products to the marketplace in a more timely manner with a more competitive price. This would ensure 
their competitiveness and expand market share, resulting in enhanced employment opportunities throughout all elements of their operations, thus improving Idaho's economy.

\section{A Technical Assistance Grant}

With the purpose of advancing the new product development competitiveness of small rural Idaho manufacturers, Boise State University (BSU) developed a matching grant with the United States Economic Development Administration (EDA) to establish a Rapid Prototyping Technical Assistance Center for Idaho manufacturers. The grant covered acquisition of a Stratasys rapid prototyping system and commercial license for a Solidworks solid-modeling package. Identification of selected individual companies began with a targeted information campaign to raise the consciousness of the Idaho manufacturing sector about these technologies. Following this campaign, a set of manufacturers in economically distressed rural counties was selected to participate in no-fee product-development projects. Objectives of the grant were to demonstrate applicability of solid modeling and rapid prototyping to (1) reduce the cost of production for established products and (2) help manufacturers bring new products to market.

The targeted information campaign began with efforts to establish communication with the desired target audience. A list of around 3500 companies involved in some form of commerce from the Idaho Manufacturers Register yielded a set of 430 prospective manufacturers that manufactured products that could take advantage of the project technologies. A telephone survey of these companies was conducted determine their level of awareness and involvement with solid modeling and prototyping technologies which resulted in contact with 236 managers who would respond to the communication. Screening questions were used to identify manufacturers meeting criteria of designing and building prototypes. Only 98 companies designed their own products, and only 43 of those actually used prototypes in their decision processes. A series of regional meetings were scheduled around the state during fall 2000 for those who both designed and used prototypes for new product decisions. These meetings served two purposes: (1) to discuss how solid modeling and rapid prototyping could benefit companies of attendees and (2) to become better acquainted with how these companies were organized and operated. This second purpose served as a means of helping decide which to select for prototyping projects. Five meeting sites were located throughout the state such that no invitee had more than a two-hour drive. In all, representatives from 25 manufacturers attended these meetings and subsequently completed applications to participate further in the grant.

It was useful to categorize companies based on the extent to which they were already using twodimensional (2D) or three-dimensional (3D) computer-aided design (CAD), computer numerical controlled (CNC) machining, and rapid prototyping (RP). Categories established were as follows:

- $\quad$ Advanced - Use 3D CAD, CNC, \& RP service bureaus

- $\quad$ Experienced - Use 3D CAD \& CNC, or 3D CAD with no RP

- $\quad$ Traditional - Use 2D CAD \& CNC, or 2D CAD with no RP

- $\quad$ Non-CAD Manufacturers - No CAD, Use either CNC or traditional prototyping

- $\quad$ Entrepreneur - No CAD or in-house prototyping capabilities

- $\quad$ Companies that appeared to have the highest degree of readiness and capacity for success from each category and provide a balance of representation from Idaho's geographic regions were chosen for the project. The first three columns of Table 1 list the type of company, experience key and locale for the 12 participants.

A site visit to each company provided a better understanding of their design and manufacturing capabilities, as well as what constituted their product line. At these meetings, project scope, timeline, and outcome expectations were established. Column four of Table 1 lists the project or projects with each company. Individual projects spanned two to four months over a period starting early 2001 and spanning early 2002. Companies with in-house solid modeling sent e-mail drawing files to BSU. Clarifications with them by telephone sufficed. Companies with 2D CAD mailed drawings to BSU that were then converted to solid model files. The software package has an "Edrawing" provision that allows simultaneous viewing and manipulating of drawings over the Internet. Coupling this 
capability with a concurrent telephone conversation provided successful communication. It was necessary for clients without CAD to visit BSU to communicate and develop their design concepts.

Table 1: Listing of Company Type, Experience Key, Locale in Idaho, and Projects

\begin{tabular}{|c|c|c|c|}
\hline Type of Company & Experience Key & Locale in Idaho & Project(s) \\
\hline $\begin{array}{l}\text { Concrete Finishing } \\
\text { Equipment }\end{array}$ & Experienced & South Western & $\begin{array}{l}\text { Handle and } \\
\text { Gearbox Case }\end{array}$ \\
\hline $\begin{array}{l}\text { Snow Removal } \\
\text { Equipment }\end{array}$ & Traditional & South Central & $\begin{array}{l}\text { Cassette and } \\
\text { Gearbox Case }\end{array}$ \\
\hline $\begin{array}{l}\text { Design \& Injection } \\
\text { Molding Services }\end{array}$ & Advanced & Northern & Helmet Visor \\
\hline $\begin{array}{l}\text { Door Handles, } \\
\text { Latches and Hinges }\end{array}$ & Traditional & South Central & $\begin{array}{l}\text { Door Knob, Latch } \\
\text { and Handle }\end{array}$ \\
\hline $\begin{array}{l}\text { Injection Molding } \\
\text { Services }\end{array}$ & $\begin{array}{l}\text { Non-CAD } \\
\text { Manufacturer }\end{array}$ & South Eastern & $\begin{array}{l}\text { Pipe Seal for Catch } \\
\text { Basin }\end{array}$ \\
\hline $\begin{array}{l}\text { Potato Handling } \\
\text { Equipment }\end{array}$ & Experienced & South Eastern & Potato Planter Cup \\
\hline $\begin{array}{l}\text { Molded Outdoor } \\
\text { Lighting Clips }\end{array}$ & $\begin{array}{l}\text { Non-CAD } \\
\text { Manufacturer }\end{array}$ & Northern & Collapsible Crate \\
\hline Shaft Encoders & Advanced & Northern & Carrier for Encoder \\
\hline $\begin{array}{l}\text { Containment } \\
\text { Testing Equipment }\end{array}$ & Entrepreneur & South Central & $\begin{array}{l}\text { Handle for } \\
\text { Specimen Sampler }\end{array}$ \\
\hline Aircraft Parts & Experienced & Northern & $\begin{array}{l}\text { Aerodynamic } \\
\text { Exhaust Stack }\end{array}$ \\
\hline $\begin{array}{l}\text { Belt Weaving } \\
\text { Machinery }\end{array}$ & Traditional & Northern & Connector Clip \\
\hline Specialty Foundry & $\begin{array}{l}\text { Non-CAD } \\
\text { Manufacturer }\end{array}$ & South Western & $\begin{array}{l}\text { Master Pattern for } \\
\text { Stamping Boss }\end{array}$ \\
\hline
\end{tabular}

\section{Experience Key}

Advanced - Use 3D CAD, CNC, \& RP service bureaus

Experienced - Use 3D CAD \& CNC, or 3D CAD with no RP

Traditional - Use 2D CAD \& CNC, or 2D CAD with no RP

Non-CAD Manufacturers - No CAD, Use either CNC or traditional prototyping

Entrepreneur - No CAD or in-house prototyping capabilities

Originally, the plan was only to produce solid models and fabricate prototypes from clients' designs, not to do any engineering design. However companies without CAD capabilities often also lacked design capabilities. So in order to ensure project success they were provided limited engineering design assistance. The use of solid modeling to develop product designs was demonstrated for seven companies not yet experienced in this technology. The solid model files were converted to Stereolithographic files for input to rapid prototyping software. All twelve companies received rapid prototype models of products they were developing. These were physical models built automatically in ABS plastic using a material additive, fused-deposition modeling (FDM) process. Only a few project participants had any previous experience with this particular RP technology.

Whenever feasible, RP models were built full scale. The build envelope in the FDM machine at BSU has a square base 10 inches on a side and height of 16 inches. While most models were built to full scale a collapsible milk-carton crate was built at half-scale since its full-scale parts would have exceeded build envelope. A small connector clip with internal pulleys was built at double design dimensions for feature clarification. A full-scale aircraft exhaust stack model larger than available envelope was built in pieces and that were bonded together. Project participants typically used RP models as part of a design refinement process. That is, evaluation of the first 
set of models pointed to the need for changes that were incorporated into a second set of models, and so forth. This allowed them to reduce the time and expense inherent in the iterative process of product design development.

\section{Results of Projects}

Generally, grant participants were pleased with their experiences in virtual solid modeling and physical rapid prototyping (McCain, et.al. 2002). The seven companies with no prior experience in solid modeling were impressed enough with its benefits that they are now embracing this CAD technology. Three companies with staff experienced in 2-D CAD were either using, beginning to use, or committed to adopting solid modeling by end of grant. The other four companies, not having staff with any CAD experience, were committed to continuing to use the technology for future product development through contract service vendors. The ten companies with no prior experience with rapid prototyping quickly recognized tangible benefits of incorporating this technology into their product development, too. These companies stated they would definitely consider rapid prototyping in the future, particularly for complex part geometry and before going into mass production. Three of these companies, now committed to regularly using this technology, have already gone into production with products developed in participation with this grant. Two of these companies introduced new products, one projected to generate $\$ 2.5$ million in revenues over 10 years and other projected to $\$ 1.6$ million over five years. The other product redesigned for injection molding will save the company $\$ 250,000$ over six years. Engineers at these three companies credited rapid prototypes with shortening development time because their availability allowed them to make informed decisions faster about part fit, form and in one case function. They also said that sharing them with management expedited the decision process in committing to production (Thompson et.al. 2002). A summary of each of the twelve companies' commitment to future applications of solid modeling and rapid prototyping, as well as the outcome of project product development at the end of the grant, is shown in Table 2.

Table 2: Listing of Company Type with Product Development Status, Use of Solid Modeling, and Use of Rapid Prototyping by End of Grant

\begin{tabular}{|c|c|c|c|}
\hline Type of Company & Product Status & Solid Modeling & Rapid Prototyping \\
\hline $\begin{array}{l}\text { Concrete Finishing } \\
\text { Equipment }\end{array}$ & $\begin{array}{l}\text { Decided to use alternative } \\
\text { designs }\end{array}$ & Already using & $\begin{array}{l}\text { Will alternate with } \mathrm{CNC} \text { as } \\
\text { appropriate }\end{array}$ \\
\hline Snow Removal Equipment & $\begin{array}{l}\text { Will not produce. Uses as } \\
\text { production reference }\end{array}$ & Starting to use & $\begin{array}{l}\text { Will consider for complex } \\
\text { part or mass production }\end{array}$ \\
\hline $\begin{array}{l}\text { Design \& Injection } \\
\text { Molding Services }\end{array}$ & $\begin{array}{l}\text { Customer decided not to } \\
\text { produce }\end{array}$ & Already Using & Already using SLA \\
\hline $\begin{array}{l}\text { Door Handles, Latches and } \\
\text { Hinges }\end{array}$ & $\begin{array}{l}\text { Producing knob and latch, } \\
\text { but not handle }\end{array}$ & $\begin{array}{l}\text { Started using during EDA } \\
\text { grant }\end{array}$ & $\begin{array}{l}\text { Started using SLA during } \\
\text { EDA grant }\end{array}$ \\
\hline Injection Molding Services & $\begin{array}{l}\text { Customer has delayed } \\
\text { production }\end{array}$ & $\begin{array}{l}\text { Will consider for future } \\
\text { projects }\end{array}$ & $\begin{array}{l}\text { Will consider for future } \\
\text { projects }\end{array}$ \\
\hline Potato Handling Equipment & In production & Already using & $\begin{array}{l}\text { Will use for molded complex } \\
\text { parts }\end{array}$ \\
\hline $\begin{array}{l}\text { Molded Outdoor Lighting } \\
\text { Clips }\end{array}$ & $\begin{array}{l}\text { Market for product being } \\
\text { explored }\end{array}$ & $\begin{array}{l}\text { Will contract for as need } \\
\text { arises }\end{array}$ & $\begin{array}{l}\text { Will contract for as need } \\
\text { arises }\end{array}$ \\
\hline Shaft Encoders & $\begin{array}{l}\text { In production with alternate } \\
\text { design }\end{array}$ & Already using & $\begin{array}{l}\text { Will alternate with CNC and } \\
\text { SLA }\end{array}$ \\
\hline $\begin{array}{l}\text { Containment Testing } \\
\text { Equipment }\end{array}$ & $\begin{array}{l}\text { Product still under } \\
\text { development }\end{array}$ & $\begin{array}{l}\text { Will consider for future } \\
\text { projects }\end{array}$ & $\begin{array}{l}\text { Will consider for future } \\
\text { projects }\end{array}$ \\
\hline Aircraft Parts & Going to production & Already using & Will use for future projects \\
\hline Belt Weaving Machinery & $\begin{array}{l}\text { To be incorporated in next } \\
\text { generation machine }\end{array}$ & Plan to adopt & $\begin{array}{l}\text { Will consider for future } \\
\text { projects }\end{array}$ \\
\hline Specialty Foundry & $\begin{array}{l}\text { Customer has delayed } \\
\text { production }\end{array}$ & May adopt in future & $\begin{array}{l}\text { Will consider for master } \\
\text { patterns }\end{array}$ \\
\hline
\end{tabular}




\section{Technology Transfer Continuation}

Concurrent to administering the work of this grant, BSU began offering product design services to Idaho industry at large through the Rapid Prototyping Technical Assistance Center created to house the equipment acquired under this grant. A not-for-profit EDA University Center entity called TechHelp manages that service. TechHelp is affiliated with BSU through the College of Business with the a mission of helping Idaho manufacturers become more competitive. This organization offers product development assistance to clients for a fee that covers engineering, equipment maintenance, supplies, and student wages. Over a two-year period, it has worked with 34 different clients on developing over 60 products using solid modeling and rapid prototyping. These clients were from ten Idaho counties, nine designated as economically distressed. Of these clients, six were companies originally served by the grant that returned for additional services on a commercial basis. Approximately 16 of these products have reached some stage of production and eight are already in the market. As a direct result of this grant, estimates for economic impact and job creation for all projects exceed $\$ 6,000,000$ and 50 jobs, respectively.

\section{Observations and Conclusions about Projects}

\section{Observations}

- Use of solid modeling as a means of creating virtual images and documenting designs has been incrementally increasing in Idaho during the last five years.

- $\quad$ Significant unfamiliarity about benefits of rapid prototyping persists among Idaho's manufacturers.

- Telephone interviews, public announcements and media coverage about design automation technologies at BSU created interest in trying them.

- When exposed to the potential of rapid prototyping, manufacturers readily move to adoption of the technology in their new product development processes.

- Manufacturers have successfully introduced several products developed as a result of the EDA grant into the marketplace.

\section{Conclusions}

- $\quad$ Solid modeling is now gaining mainstream acceptance as the graphical package of choice for product design.

- $\quad$ Manufacturers' attitudes about using rapid prototyping are changing based their positive experiences during the EDA sponsored projects.

- $\quad$ Presence of a Rapid Prototyping Technical Assistance Center has accelerated the infusion of design automation technologies into rural Idaho's product design.

- $\quad$ Personal experience is an important component in rural manufacturers' decisions to adopt RP technologies in new product development.

- Infusion of design automation technologies into product development is starting to have a positive impact on Idaho's rural economy.

Companies participating in the projects involved in this project were able to become a bit more competitive as a result of advancing their technological knowledge base. Although routine production jobs will continue to migrate to lower cost parts of the world for large volumes, these small and rural companies have strengthened their position by improving their ability to introduce ideas that solve customer problems to the market faster and reducing their cost of design development through rapid prototyping.

\section{Suggestions for Future Research}

While the economic benefits derived from some of the products described in this paper will help their companies generate profits and expand employment in the state of Idaho, some of the products designed and prototyped for companies through this grant appear to have no real potential for market acceptance. Some products may have market potential, but the market for them is different enough from the market currently served by their 
developer that the companies do not know how to make them successful. Development of the physical characteristics of a prototype does not provide any indication of the market potential of a product. A good product idea does not convey the ability to sell that idea to the right customers.

For a technical assistance center to truly provide small rural companies the kind of new product development assistance they need to truly achieve market competitiveness with more advanced technologies, it needs to provide those companies with a comparable level of marketing competence.

The primary technology used in this project was the fused deposition modeling rapid prototyping equipment. There are other equipment options with differing properties that are more appropriate for some design and product situations.

A proposal for a grant to expand access to additional prototyping technologies and provide managers with marketing management education and assistance was submitted to the Economic Development Administration. This grant has been approved and a project has been initiated to provide enhanced new product development assistance to small rural manufacturers in Idaho and other states associated with Idaho businesses.

\section{References}

1. Annett, Tim, Ballinger, and Creighton, The Wall Street Journal Online, 7 April, 2004

2. Aoki, Naomi, Globe Staff, "Inventing Designer Drugs by Moving to Cambridge, Novartis Bets \$4 Billion It Can Revamp the Science of the Pharmaceutical Industry [Third Edition]," Boston Globe, pp. D.1 13 April 2003.

3. Brown, Alan, "The many favors of open", Mechanical Engineering, Vol. 122, No. 3, pp. 58-63, March 2000.

4. Davis, Bob, "Wealth of Nations: Finding Lessons Of Outsourcing In 4 Historical Tales; Technology, Trade, Migration Often Shook Job Market; Politics Can Slow Effects; Farmers Fall Prey to Railroads," Wall Street Journal (Eastern edition). New York, N.Y., pp. A.1, 29 March 2004.

5. DeGaspari, John, "Rapid evolution: new materials and process improvements are stretching boundaries of prototyping techniques", Mechanical Engineering, Vol. 124, No. 3, pp. 48-52, March 2002.

6. Gavin, Robert, "Foreign companies Called Big Employers: Trade Group's Report Takes Aim At Concerns about Outsourcing", Boston Globe, pp. G1, 20 April 2004.

7. $\quad$ Hayes, Jack, Rapid Prototyping Allows Fast Design Changes, R \& D, pp. 46-49, March 1998.

8. Matlack, Carol, et al, "Job Exports: Europe's Turn," Business Week, Issue 3879, pp50, 2p, 1c, 19 April 2004.

9. McCain, G., Tennyson, S.A., Eggert, R.J., "An Engineering and Marketing Collaboration for Live-Case Technology Transfer to Rural Manufacturers," Proceedings of the World Association for Case Method Research and Application, Mannheim Germany, June, 2002.

10. McCain, G., Tennyson, S.A., Manufacturers' understanding of solid-modeling and prototyping technologies in economic distressed areas in the state of Idaho, Final Report to Boise State University, Faculty Research Grant, No. 2, June 2001.

11. Phillips, Michael M., "Outsourcing Fears Land in Congress's Lap; Legislators Debate a Number of Measures That Respond to Political Hot Potato," Wall Street Journal (Eastern edition), New York, pp. A.4, March 5, 2004

12. Roth, Terence, Bahree, Bhushan, "Europe, Despite Rising Joblessness, Isn't Likely to Turn Protectionist" Wall Street Journal (Eastern edition). New York, N.Y., pp. A9C (2 pages), 1 April 1996.

13. Smith, Preston, "Using conceptual modelers for business advantage", Time-Compression Technologies, Vol. 6, No. 3, pp. 19-24, April 2001.

14. State of Idaho, Idaho Economic Forecast, Division of Financial Management, XX, no. 1, 1998.

15. Tennyson, S.A., Eggert, R.J., "Engineering Design Graphics in Idaho, a 1999 Industry and Academic Benchmark," Engineering Design Graphics Journal, Vol. 64, Spring 2000.

16. Thompson, G.W., Tennyson, S.A., Eggert, R.J., McCain, G., "Transferring Rapid Prototyping to Idaho Small Business," Final Report to EDA University Center Program, Project No. 07-69-04727, July, 2002. 
17. Webb, Alysha, "Outsourcing to ease strain on VW capacity," Automotive News Europe, Vol. 8, Issue 11, pp.1, 2 June 2003.

18. Wessel, David, "Barbell Effect -- The Future of Jobs: New Ones Arise, Wage Gap Widens; Outsourcing, Technology Cut Need for Rote Workers; Brainpower Is in Demand; Hot Area: Massage Therapy," Wall Street Journal (Eastern Edition), pp. A1, April 2.

19. Wohlers, Terry, "Rapid Production with Rapid Prototyping", Computer-Aided Engineering, pp. 18-24 April 2000 .

Notes 